\title{
Phylogenetics and antibacterial properties of exopolysaccharides from marine bacteria isolated from Mauritius seawater
}

\author{
Aadil Ahmad Aullybux ${ }^{1} \cdot$ Daneshwar Puchooa ${ }^{1} \cdot$ Theeshan Bahorun $^{2} \cdot$ Rajesh Jeewon $^{3}$
}

Received: 19 March 2019 / Accepted: 22 May 2019 / Published online: 13 June 2019

(C) Università degli studi di Milano 2019

\begin{abstract}
Purpose The marine environment harbours diverse bacterial species which can be exploited for the production of valuable compounds such as exopolysaccharides (EPS) which hold promises for biotechnological applications. The coastal waters of Mauritius is a relatively underexplored marine environment and in this study, isolated bacterial species were tested for the production of EPS exhibiting antibacterial properties against human bacterial pathogens from the genera Acinetobacter, Bacillus, Campylobacter, Enterobacter, Enterococcus, Escherichia, Proteus, Pseudomonas, Salmonella, Streptococcus and Staphylococcus.

Methods Bacteria were first isolated from seawater samples. Using the disc diffusion method, their EPS were tested for antibacterial effects through two screenings, with each involving a different set of arbitrarily chosen group of pathogens. The microorganisms producing antibacterial EPS were subsequently identified by morphological, biochemical and 16S rRNAbased phylogenetic analyses. Those EPS exhibiting broadest antibacterial activities were eventually characterised by Fouriertransform infrared spectroscopy (FTIR) and thin-layer chromatography (TLC).

Results Eight EPS were found to display antibacterial effects against more than half of the pathogens and the microorganisms producing them were identified as Bacillus, Halomonas, Psychrobacter and Alcaligenes species. However, only two of these EPS were found to be the most active, with their MIC values ranging between 62.5 and $500 \mu \mathrm{g} / \mathrm{ml}$. FTIR and TLC analyses revealed the presence of carboxyl, hydroxyl and amide as well as sulphate for the EPS, with glucose or fructose being the main sugar.

Conclusion The results suggest that Mauritius seawater can be a source of biotechnologically useful microorganisms, producing EPS having potential as antimicrobial agents. DNA sequence data also suggest possible novel bacterial species.
\end{abstract}

Keywords Antimicrobial $\cdot$ Bacteria $\cdot$ Exopolysaccharides $\cdot$ Mauritius $\cdot$ Phylogeny $\cdot$ Seawater

Electronic supplementary material The online version of this article (https://doi.org/10.1007/s13213-019-01487-2) contains supplementary material, which is available to authorized users.

Aadil Ahmad Aullybux

aaa2891@live.com

$\triangle$ Rajesh Jeewon

r.jeewon@uom.ac.mu

1 Department of Agricultural and Food Science, Faculty of Agriculture, University of Mauritius, Réduit, Republic of Mauritius

2 ANDI Centre for Biomedical and Biomaterials Research (CBBR) and Department of Biosciences and Ocean Studies, Faculty of Science, University of Mauritius, Réduit, Republic of Mauritius

3 Department of Health Sciences, Faculty of Science, University of Mauritius, Réduit, Republic of Mauritius

\section{Introduction}

Over the past few years, there has been increasing interests in the development of natural polymers, also known as biopolymers, for use in industries as well as for other biotechnological applications (Singha 2012). In this respect, polysaccharides, representing the largest group of produced biopolymers, have often been produced from plants for use mainly as food additives (Vuyst et al. 1998; Poli et al. 2011). However, attention was subsequently shifted to microbial polysaccharides or exopolysaccharides (EPS), the main component of the extracellular polymeric substances. These macromolecules, formed by the polymerisation of sugar residues (Bragadeeswaran et al. 2011; Pawar et al. 2013), are widely diverse in nature with varying molecular weights $(10-1000 \mathrm{kDa})$ and may be classified as either homopolysaccharides, if they consist of 
only one type of monosaccharide, or heteropolysaccharides, if they consist of multiple ones (Nwodo et al. 2012). Interest in EPS lies mainly in their diversity, with different types of microorganisms producing EPS which vary in terms of composition, size and structure (Yadav et al. 2011). This variation, attributed to differences in the number and types of functional groups attached to the EPS, yields polymers of different properties (Nichols et al. 2005), thereby allowing them to have a wide range of physiological functions within microorganisms such as retention of nutrients to prevent starvation (Singha 2012), in biofilm formation (Vu et al. 2009), for establishing symbiotic relationships (Jones 2012) or for protection against desiccation and presence of toxins or antibiotics in their surroundings (Singha 2012). It is, therefore, not surprising to note that such wide diversity in properties and functions has also made possible numerous industrial applications including in food, cosmetics, textile, pharmaceutical, agricultural, paint, petroleum and waste water treatment among others (Cojoc et al. 2009; Im et al. 2010; Laurienzo 2010).

Currently, the potential applications of EPS in medicine are of particular interest because not only have they been described as useful for medical purposes such as arthritis treatment, wound dressings, surgery or pharmaceutical capsules (Moscovici 2015), but the widely documented health benefits of these compounds, especially from Lactobacillus species, have also prompted investigations on their uses as probiotics (Panthavee et al. 2017; Dinić et al. 2018; Khalil et al. 2018). More recently, biological activities of exopolysaccharides have been reported, with a number of recent studies documenting their immunostimulatory, antiviral, anti-oxidative, anti-tumour and antibacterial properties (Balzaretti et al. 2017; Zhou et al. 2017; Reichert et al. 2017; El-Deeb et al. 2018; Wen et al. 2018). The latter represents an interesting prospect in view of the increasing resistance of pathogenic microorganisms to existing antibiotics (Ghalem 2017). Indeed, drug-resistant microorganisms have become an increasing concern and the potential of microbial exopolysaccharides in fighting microbial resistance lies both in their intrinsic biological activities and their ability to be used in drug delivery systems (El-Naggar et al. 2016; Sezer et al. 2017). Furthermore, EPS with such characteristics may also find applications in food coatings for longer preservation as it is the case for the polysaccharide pullulan (Morsy et al. 2015; Trinetta and Cutter 2016). Hence, screening for new sources of microbial exopolysaccharides may eventually help in developing new antibacterial compounds with different potential applications. The choice of EPS from marine microorganisms is not merely based on the fact that marine microbial natural products, especially those of pharmaceutical value, have become increasingly popular (Debbab et al. 2010). The sea, actually, offers a wider range of biological diversity (Zheng et al. 2011) while at the same time, the aquatic ecosystem, being completely different from the terrestrial one, has caused marine microbes to develop different metabolic and physiological abilities for survival, thereby allowing the production of new compounds not found in terrestrial organisms (Soria-Mercado et al. 2012). As far as microbial extracellular polysaccharides are concerned, the marine environment, therefore, offers greater potential of obtaining new EPSproducing microorganisms as well as novel EPS as demonstrated in some studies (Liu et al. 2013; Gugliandolo et al. 2014; Sun et al. 2015). While it has also been common practice to screen the marine environment for biotechnologically useful microorganisms, such has not been the case of the island of Mauritius. In fact, despite having a very large exclusive economic zone, its marine area has remained largely unexplored with respect to its microbial diversity as well as their potential biotechnological applications. The objectives of this study are as follows: (i) isolate bacterial species from sea water and characterise them based on morphology, biochemistry and DNA sequence data; (ii) extract extracellular polysaccharides from selected bacterial species and assess their antibacterial properties against various human pathogens, including methicillin-resistant Staphylococcus aureus.

\section{Materials and methods}

\section{Sample collection}

Sampling was carried out during the summer period (November 2014 to April 2015) from three different locations in Mauritius namely Flic en Flac (coordinate 1: $20^{\circ} 19^{\prime} 29^{\prime \prime} \mathrm{S}$; $57^{\circ} 22^{\prime} 8^{\prime \prime}$ E), Tamarin (coordinate 2: $20^{\circ} 19^{\prime} 32^{\prime \prime} \mathrm{S} ; 57^{\circ} 22^{\prime}$ $33^{\prime \prime}$ E) and La Preneuse (coordinate 3: $20^{\circ} 21^{\prime} 40^{\prime \prime}$ S; $57^{\circ} 21^{\prime}$ $23^{\prime \prime}$ E). Thirty seawater samples were collected in sterile 125 $\mathrm{ml}$ bottles at maximum depth for these sampling sites (between 10 and $15 \mathrm{~m}$ ) and they were kept on ice until transported to the laboratory where they were stored at $4{ }^{\circ} \mathrm{C}$ until use within $24 \mathrm{~h}$. Physical parameters such as temperature, $\mathrm{pH}$ and salinity of the water samples were also taken.

\section{Isolation of EPS-producing organisms}

Each collected sample was serially diluted in filtered autoclaved seawater and subsequently plated onto four different media namely Plate Count Agar (PCA), Zobell ${ }^{\mathrm{TM}}$ Marine Agar (MA) 2216 (HiMedia®), R2A Agar (HiMedia ${ }^{\circledR}$ ) and Seawater (SW) Agar, which was autoclaved seawater supplemented with $1.5 \%(w / v)$ agar. Plating was carried out in duplicate and the plates were incubated at the same temperature as the collected samples for $24-48 \mathrm{~h}$ in the case of MA and PCA while incubation for 3 up to 7 days was carried out for the other two media. In order to obtain additional microorganisms which may be better adapted for growth using seawater as a natural liquid media, samples were also inoculated into 
filtered autoclaved seawater and incubated for at least 1 week prior to plating onto SW agar. All incubations were carried out not only aerobically but also under anaerobic as well as microaerophilic conditions so that microorganisms with different growth requirements may also be recovered. In this case, plates were kept in airtight jars together with AnaeroGen $^{\mathrm{TM}}\left(\mathrm{Oxoid}^{\mathrm{TM}}\right)$ and Campygen ${ }^{\mathrm{TM}}$ (Oxoid $^{\mathrm{TM}}$ ) sachets for generating anaerobic and microaerophilic atmospheres respectively. Colonies showing visually different characteristics including colour and shape were eventually selected and subcultured on the same medium used as for isolation until pure cultures were obtained. Pure cultures were maintained and stored at $4{ }^{\circ} \mathrm{C}$.

\section{Production and purification of exopolysaccharides by selected organisms}

Single colonies of selected isolates were used to inoculate Zobell Marine Broth (HiMediaß) supplemented with 5\% $(w / v)$ glucose. After 5-day incubation, exopolysaccharides were extracted based on the method described by Al-Nahas et al. (2011), with modifications. Briefly, culture broth was centrifuged at $5000 \mathrm{rpm}$ for $10 \mathrm{~min}$ to pellet cells, after which three volumes of ice-cold absolute ethanol was added to the supernatant before overnight storage at $4{ }^{\circ} \mathrm{C}$ to allow precipitation of EPS. The mixture was then centrifuged at $5000 \mathrm{rpm}$ for $20 \mathrm{~min}$ to collect the polysaccharides. Purification of EPS was carried out by first dissolving the EPS in a minimum amount of water followed by addition of an equal amount of $20 \%(w / v)$ trichloroacetic acid prior to overnight incubation at $4{ }^{\circ} \mathrm{C}$ in order to precipitate proteins. After centrifugation at $5000 \mathrm{rpm}$ for $15 \mathrm{~min}$ to remove protein pellets, the resulting supernatant was further purified by dialysis (MW cutoff $12,000 \mathrm{Da}$, Sigma) against distilled water for $48 \mathrm{~h}$ at $4{ }^{\circ} \mathrm{C}$. The purified EPS was again precipitated by addition of three volumes of ice-cold absolute ethanol and collected by centrifugation. The resulting pellet was eventually dried to constant mass at $65{ }^{\circ} \mathrm{C}$ prior to storage at $4{ }^{\circ} \mathrm{C}$.

\section{Preliminary screening for antimicrobial activity}

In order to identify EPS with antibacterial properties, the disc diffusion assay, according to Balouiri et al. (2016), was carried out against seven human pathogenic bacteria-the Grampositive Bacillus cereus ATCC 10876, Staphylococcus aureus ATCC 29213 and a clinical strain of Staphylococcus saprophyticus as well as the Gram-negative Escherichia coli ATCC 25922, Salmonella typhimurium ATCC 14028, Enterobacter cloacae ATCC 13047 and Proteus mirabilis ATCC 12453. The test strains were inoculated in MullerHinton broth and allowed to grow for $24 \mathrm{~h}$ at $37{ }^{\circ} \mathrm{C}$. Cultures were then adjusted to a turbidity of $0.5 \mathrm{McF}$ arland (absorbance $0.08-0.1$ at $600 \mathrm{~nm}$ ) and $100 \mu \mathrm{l}$ of the standardised test strain cultures were plated onto MullerHinton agar. Dried EPS from each isolated organism was dissolved in sterile distilled water to a final concentration of $5 \mathrm{mg} / \mathrm{ml}$ and $10 \mu \mathrm{l}$ of each sample was applied to $6-\mathrm{mm}$ sterile discs which were subsequently placed on the agar inoculated with test strains. Plates were incubated in upright position for $18 \mathrm{~h}$ at $37^{\circ} \mathrm{C}$. Zones of inhibition around discs were taken as an indication of antimicrobial activity and results for each extract was recorded as the diameter (to the nearest $0.5 \mathrm{~mm}$ ) of the zone of inhibition produced around each disc. Isolates showing activity against a minimum of four test strains were then selected for further work.

\section{Morphological and biochemical characterisation of selected isolates}

Single colonies of the isolates selected from the preliminary screening were first visualised for their general characteristics as described by Smibert and Krieg (1994). This was followed by their biochemical characterisation based on Bergey's Manual of Determinative Bacteriology (Holt et al. 1994) with tests ranging from the regular Gram-staining for determining bacterial morphology to other biochemical tests including catalase, oxidase, sugar fermentation, urease, sulphite, indole, motility, gelatinase, methyl red-Voges-Proskauer and nitrate reduction.

\section{DNA extraction}

DNA was extracted from the selected isolates using the method described by Wilson (2003) with a slight modification. Briefly, $1.5 \mathrm{ml}$ of an overnight-grown culture was centrifuged at 13,000 rpm for $2 \mathrm{~min}$ and the resulting pellet was dissolved in $567 \mu \mathrm{l}$ of TE buffer $(10 \mathrm{mM}$ Tris $\mathrm{pH} 8.0$ and $1 \mathrm{mM}$ EDTA $\mathrm{pH} 8.0)$. Two microlitres of lysozyme $(50 \mathrm{mg} / \mathrm{ml})$ was added and the mixture was incubated for $30 \mathrm{~min}$ at $37{ }^{\circ} \mathrm{C}$ before addition of $30 \mu \mathrm{l}$ of $10 \%(w / v)$ SDS as well as $3 \mu \mathrm{l}$ of Proteinase K $(20 \mathrm{mg} / \mathrm{ml})$. This was followed by another incubation for $1 \mathrm{~h}$ at $37^{\circ} \mathrm{C}$ after which $100 \mu \mathrm{l}$ of $5 \mathrm{M} \mathrm{NaCl}$ and $80 \mu \mathrm{CTAB} / \mathrm{NaCl}(10 \%(w / v) \mathrm{CTAB}$ in $0.7 \mathrm{M} \mathrm{NaCl})$ was added. The mixture was then incubated at $65^{\circ} \mathrm{C}$ for $10 \mathrm{~min}$. An equal volume of phenol/chloroform/isoamyl alcohol (25:24:1) was added and the mixture was subsequently centrifuged for $5 \mathrm{~min}$ at maximum speed prior to the transfer of the upper layer to a fresh microcentrifuge tube. The same process was repeated a second time using chloroform/ isoamyl alcohol (24:1). To the aqueous layer, 0.6 volume of ice-cold isopropanol was added and after 1-h incubation, the mixture was centrifuged at $4^{\circ} \mathrm{C}$. The resulting pellet was then washed with $70 \%(v / v)$ ethanol, dried and diluted in TE buffer before being run on $1 \%(w / v)$ agarose gel to check for the presence of DNA. 


\section{PCR amplification of 16S rRNA and DNA sequencing}

The 16S rRNA (1400-1500 bp) was amplified by PCR using the primer pairs 27F (5'-AGAGTTTGATCATGGCTCAG) and 1492R (5'-CGGTTACCTTGTTACGACTT) as forward and reverse primers respectively (Frank et al. 2008). Reactions were carried out in $25-\mu \mathrm{l}$ reaction volumes using the following components: DreamTaq ${ }^{\mathrm{TM}}$ buffer $(2.5 \mathrm{mM} \mathrm{MgCl} 2)$, dNTP $(0.05 \mathrm{mM})$, Primers $(0.4 \mu \mathrm{M})$ each, DreamTaq ${ }^{\mathrm{TM}}$ DNA polymerase $(1.5 \mathrm{U})$ and $40 \mu \mathrm{g}$ DNA. PCR runs were carried out with the following parameters: initial denaturation for $5 \mathrm{~min}$ at $95^{\circ} \mathrm{C}$, followed by 30 cycles, each having a denaturation step at $95{ }^{\circ} \mathrm{C}(1 \mathrm{~min})$, an annealing step at $55^{\circ} \mathrm{C}(1 \mathrm{~min})$ and extension step at $72{ }^{\circ} \mathrm{C}(1 \mathrm{~min})$ before a final extension at $72{ }^{\circ} \mathrm{C}$ for $5 \mathrm{~min}$. Amplified products were purified and sent for sequencing with primers mentioned above at Inqaba Biotech South Africa.

\section{Identification of selected isolates and phylogenetic analyses}

The 16S rRNA sequences were compared to those of validly published species available in the database of the National Centre for Biotechnology Information (NCBI) using the Basic Local Alignment Search Tool (BLAST). Pairwise nucleotide similarity values between the reference strains and the isolates were determined using the EZBioCloud server (https://www.ezbiocloud.net/) (Yoon et al. 2017). Sequences of closely related species were retrieved and aligned with query sequences using ClustalW (Thompson et al. 1994). Using PAUP 4.0 (Swofford 2002), phylogenetic trees were subsequently constructed using three different tree building methods namely maximum parsimony (Fitch 1971), maximum likelihood (Felsenstein 1981), with the nucleotide substitution model determined using jModelTest (Guindon and Gascuel 2003; Darriba et al. 2012) and eventually neighbour-joining method (Saitou and Nei 1987), for which distance matrices were generated based on Kimura's twoparameter model (Kimura 1980). The robustness of the tree topologies was evaluated using bootstrap analysis, with 1000 replications of the neighbour-joining method, 500 replications of the maximum parsimony and 100 replications of maximum likelihood.

\section{Secondary screening - antimicrobial activity of EPS from selected isolates and minimum inhibitory concentration}

In order to differentiate between the selected EPS for identifying only those exhibiting the broadest range of antibacterial activity, a second set of screening was carried out using only those extracts selected during the previous screening to further compare their biological activity. For this purpose, EPS was extracted as described before and disc diffusion assay was again performed but in this case, against a different set of seven pathogenic strains consisting of Enterococcus faecalis ATCC 29212, Streptococcus pneumonia ATCC 49619, Streptococcus agalactiae ATCC 27956, Campylobacter jejuni NCTC 11351 and three more clinical strains namely methicillin-resistant Staphylococcus aureus, Pseudomonas aeruginosa and a species of Acinetobacter.

This was followed by broth microdilution assay to determine the minimum inhibitory concentration (MIC) of each polysaccharide extract used in the secondary screening against all the 14 pathogenic strains (Balouiri et al. 2016). Basically, $50 \mu \mathrm{l}$ of Muller-Hinton broth was added to each well of a 96well microtitre plate. This was followed by the addition of $50 \mu \mathrm{l}$ of $8 \mathrm{mg} / \mathrm{ml}$ EPS to the first well of each column. Fifty microlitres from the first well was then transferred to the second well, leading to a twofold dilution of the EPS and this was repeated up to the eighth well, with frequent pipetting before each transfer for proper mixing. Eventually, from the last one, $50 \mu \mathrm{l}$ was removed and discarded in order to keep a constant volume in each well. Test strains were cultured as before and were diluted to a concentration of $1 \times 10^{6} \mathrm{CFU} / \mathrm{ml}$. Fifty microlitres of that diluted test strain was dispensed into each well to reach a final concentration of $5 \times 10^{5} \mathrm{CFU} / \mathrm{ml}$ per well and the plates were incubated for $18-20 \mathrm{~h}$ under appropriate conditions required for the growth of the pathogenic strains. For each plate, chloramphenicol and Muller-Hinton broth with extract only were used as negative controls while for positive control, inoculated broth without extract was used. After incubation, inhibitory activity of EPS was observed using the method of Eloff (1998). Ten microlitres of piodonitrophenyltetrazolium violet (INT) $-0.2 \mathrm{mg} / \mathrm{ml}$ — was added to each well and the presence of a red coloration indicated the presence of viable cells and hence absence of antimicrobial activity. INT was added to each well of a column until red coloration was obtained for two or more consecutive wells. The MIC value was taken as the minimum concentration of EPS for which no colour change was observed. Results were analysed using two-way ANOVA with test strains and EPS extracts as variables (Minitab 17) to check for differences at 5\% significance level.

\section{Chemical characterisation of extracellular polysaccharides}

The total carbohydrate content of the polysaccharides with the broadest range of antibacterial activity was spectrophotometrically determined by the phenol-sulphuric acid method (Dubois et al. 1956) using glucose as standard while the presence of protein was determined, using bovine serum albumin as standard, by the Lowry method (Lowry et al. 1951). Sulphate content was also measured as described by Ji et al. (2013), with dipotassium sulphate as standard. 


\section{Analysis of monosaccharide composition}

The monosaccharide composition of selected exopolysaccharides was qualitatively determined by thinlayer chromatography. The EPS was first hydrolysed, as described by Zhang et al. (2016), with $2 \mathrm{~N}$ sulphuric acid for $4 \mathrm{~h}$ at $100{ }^{\circ} \mathrm{C}$. The hydrolysed samples were subsequently concentrated prior to application on silica gels (Merck) along with the reference sugars glucose, fructose, rhamnose, ribose, arabinose, xylose and galactose. The chromatogram was developed using acetone/butanol/ $\mathrm{H}_{2} \mathrm{O}(8: 2: 2)$ for neutral sugars, butanol/ethanol/ $\mathrm{H}_{2} \mathrm{O}(5: 3: 2)$ for oligosaccharides and butanol/ $\mathrm{H}_{2} \mathrm{O} /$ acetic acid (3:1:1) for acidic sugars (Manca et al. 1996). Visualisation was done by spraying with ethanolic $p$ anisaldehyde reagent ( $1 \mathrm{ml} p$-anisaldehyde, $1 \mathrm{ml}$ conc. sulphuric acid in $20 \mathrm{ml}$ ethanol), $\alpha$-naphtol-trichloroacetic acid (equal volumes of $0.2 \%$ ethanolic $\alpha$-naphtol $+20 \%$ aqueous trichloroacetic acid) and ninhydrin for detection of sugars, uronic acids and amide groups respectively.

\section{Attenuated total reflection Fourier-transform infrared spectroscopy}

Attenuated total reflection Fourier-transform infrared spectroscopy (ATR-FTIR) analysis (Bruker Alpha-T) was carried out in order to determine the functional groups present in the exopolysaccharides which were effective against most pathogens. The samples were directly analysed and the spectra were acquired on OPUS Spectroscopy Software (Bruker) in the range $4000-100 \mathrm{~cm}^{-1}$ at $2 \mathrm{~cm}^{-1}$ spectral resolution and with 25 scans.

\section{Results}

\section{Sample collection and isolation}

For all samples collected, temperature recorded was quite uniform ranging between 27 and $29^{\circ} \mathrm{C}$, with $\mathrm{pH}$ being between 8.2 and 8.4. Salinity was also uniform with an average of $3.2 \%$. The seawater showed high microbial load with values between $10^{6}$ and $10^{7} \mathrm{CFU} / \mathrm{ml}$. This was reflected in the large number of colonies obtained on the different media but eventually, 40 colonies were selected for EPS production based on morphological differences or their mucoid nature.

\section{Preliminary screening}

For the preliminary screening, most extracts showed antibacterial activity against at least one test strain, with Figs. 1 and 2 showing the observed zones of inhibition for some of the extracts. Overall, Gram-negative bacteria were more susceptible than the Gram-positive ones. As shown in Table 1, of all

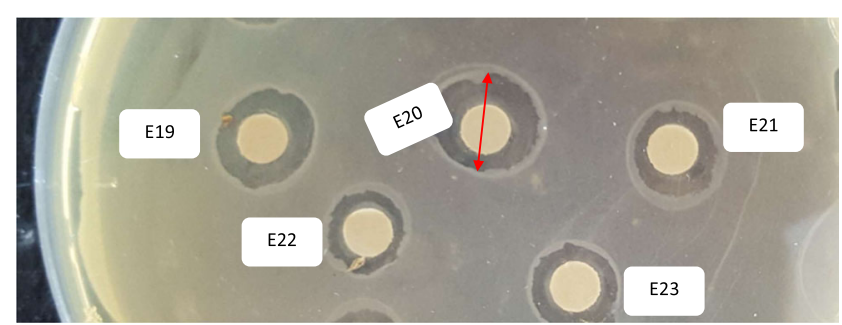

Fig. 1 Antibacterial activity of EPS extracts E19, E20, E21, E22 and E23, with red arrow showing diameter of zones of inhibition

the EPS tested, only eight-E5, E15, E16, E18, E19, E20, E26 and E37-(from isolates EPS-5, EPS-15, EPS-16, EPS18, EPS-19, EPS-20, EPS-26, EPS-37 respectively) were active against a minimum of four pathogenic strains and were, therefore, selected for further screening as a result of their broader range of activity.

\section{Morphological and biochemical characterisation of isolates}

Six of the isolates showed similar colony morphology when grown on marine agar, with the colonies being circular, smooth and elevated (Fig. 1) (Supplementary Material), while the remaining two (EPS-20 and EPS-26) were mostly irregular in shape (Fig. 2) (Supplementary Material). Other characteristics of the selected microorganisms were as shown in Table 1 (Supplementary Material) while the source of their isolation, including media on which they have been isolated were as shown in Table 2 (Supplementary Material).

All the isolates were also found to be motile as well as Gram-negative, except for EPS-20 and EPS-26. They were also rod-shaped except for EPS-5 which was coccus-shaped. Further biochemical characterisation showed that all of them were negative for methyl red-Voges-Proskauer tests as well as for indole production. They were also unable to use citrate or gelatin as carbon source with both tests being negative. However, they were all catalase and oxidase positive. Results of the remaining tests for which differences were observed are summarised in Table 3 (Supplementary Material).

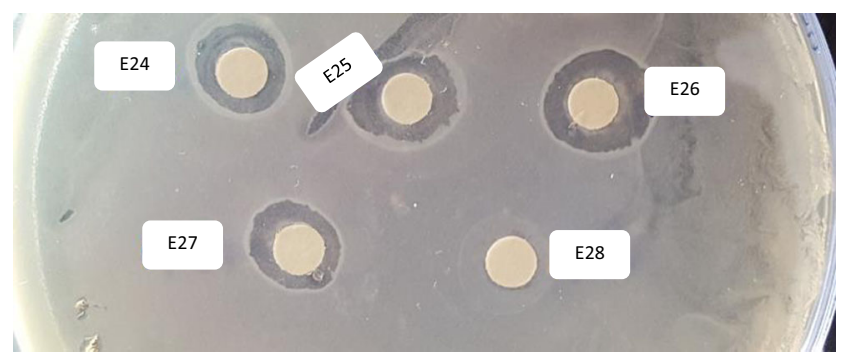

Fig. 2 Zones of inhibition produced by E24, E25, E26 and E27, with absence of antibacterial activity for E28 
Table 1 Activity of EPS from isolates against test strains for primary screening

\begin{tabular}{|c|c|c|c|c|c|c|c|}
\hline \multirow[t]{2}{*}{ EPS } & \multicolumn{7}{|l|}{ Test strains } \\
\hline & $\begin{array}{l}\text { Enterobacter } \\
\text { cloacae }\end{array}$ & $\begin{array}{l}\text { Salmonella } \\
\text { typhimurium }\end{array}$ & $\begin{array}{l}\text { Escherichia } \\
\text { coli }\end{array}$ & $\begin{array}{l}\text { Staphylococcus } \\
\text { aureus }\end{array}$ & $\begin{array}{l}\text { Staphylococcus } \\
\text { saprophyticus }\end{array}$ & $\begin{array}{l}\text { Bacillus } \\
\text { cereus }\end{array}$ & $\begin{array}{l}\text { Proteus } \\
\text { mirabilis }\end{array}$ \\
\hline E1 & + & - & - & + & - & - & - \\
\hline E2 & + & - & - & - & - & - & - \\
\hline E3 & + & - & - & + & - & - & - \\
\hline E4 & + & + & - & + & - & - & - \\
\hline E5 & $9.8 \pm 0.1$ & $9.9 \pm 0.2$ & - & $7.4 \pm 0.2$ & $7.0 \pm 0.2$ & - & $9.0 \pm 0.1$ \\
\hline E6 & + & - & - & - & - & - & + \\
\hline E7 & + & - & - & + & + & - & - \\
\hline E8 & - & - & - & + & + & - & + \\
\hline E9 & + & - & - & - & - & - & + \\
\hline E10 & + & - & - & - & - & - & - \\
\hline E11 & - & - & - & + & - & - & + \\
\hline E12 & + & - & - & + & - & - & + \\
\hline E13 & - & - & - & - & - & - & + \\
\hline E14 & - & + & - & - & - & + & + \\
\hline E15 & $10.9 \pm 0.2$ & $7.8 \pm 0.1$ & - & $9.5 \pm 0.1$ & - & - & $8.9 \pm 0.2$ \\
\hline E16 & $10.6 \pm 0.2$ & $7.9 \pm 0.1$ & - & $10.0 \pm 0.4$ & - & - & $8.6 \pm 0.1$ \\
\hline E17 & - & - & - & + & - & + & + \\
\hline E18 & $10.8 \pm 0.1$ & $9.4 \pm 0.4$ & - & $8.1 \pm 0.1$ & $7.6 \pm 0.3$ & - & $8.0 \pm 0.1$ \\
\hline E19 & $7.9 \pm 0.2$ & $9.5 \pm 0.1$ & - & $8.1 \pm 0.2$ & $8.6 \pm 0.2$ & - & $11.0 \pm 0.2$ \\
\hline E20 & $10.1 \pm 0.3$ & $6.4 \pm 0.1$ & - & $9.1 \pm 0.1$ & $7.1 \pm 0.3$ & - & $11.9 \pm 0.2$ \\
\hline E21 & + & - & - & - & - & - & + \\
\hline E22 & + & - & - & - & - & - & + \\
\hline E23 & - & - & - & + & - & - & + \\
\hline E24 & - & - & + & - & + & - & + \\
\hline E25 & + & - & - & + & + & - & + \\
\hline E26 & $11.4 \pm 0.2$ & - & $9.5 \pm 0.1$ & $8.0 \pm 0.4$ & $8.1 \pm 0.2$ & - & $9.9 \pm 0.1$ \\
\hline E27 & - & - & + & + & - & - & + \\
\hline E28 & + & - & - & - & + & - & - \\
\hline E29 & - & - & - & + & + & - & + \\
\hline E30 & - & - & - & + & + & - & + \\
\hline E31 & - & - & - & + & + & - & + \\
\hline E32 & - & - & - & + & + & - & + \\
\hline E33 & - & - & - & - & + & - & + \\
\hline E34 & + & + & - & - & - & - & - \\
\hline E35 & - & + & - & + & + & - & - \\
\hline E36 & - & - & + & + & + & - & - \\
\hline E37 & $9.0 \pm 0.2$ & $7.1 \pm 0.2$ & $7.6 \pm 0.1$ & $9.1 \pm 0.2$ & - & - & - \\
\hline E38 & + & - & - & - & - & - & - \\
\hline E39 & - & - & - & - & - & - & - \\
\hline $\mathrm{E} 40$ & - & - & - & - & - & - & - \\
\hline
\end{tabular}

+ indicates activity; - indicates no activity; values for diameter of zones of inhibition shown only for selected EPS as diameter (in millimetres) \pm standard deviation; 
DNA-based identification and phylogenetic analyses

Based on 16S rRNA sequences (between 1400 and $1500 \mathrm{bp}$ ), it was found that the eight selected isolates could be assigned to two main bacterial phyla namely Proteobacteria and Firmicutes (Figs. 3, 4, 5 and 6). From the phylum Proteobacteria, only EPS-37 belonged to the class Alphaproteobacteria, and closely related to Alcaligenes faecalis (Fig. 3), with which it shared $99.5 \%$ nucleotide sequence similarity. Five other isolates from the same phylum could be assigned to the class Gammaproteobacteria and among these, one (EPS-5) was identified as belonging to the genus Psychrobacter, with the isolate having $P$. ciconiae as its closest phylogenetic relative (Fig. 4). Interestingly, this isolate formed an independent lineage from the P. ciconiae subclade and shared only $96.1 \%$ nucleotide similarity with the type strain of $P$. ciconiae. The remaining four isolates were identified as members of the genus Halomonas. In this case, EPS-15 and EPS16 formed a distinct clade with $H$. venusta species while EPS-18 and EPS-19 were more closely related to $H$. aquamarina and $H$. meridiana respectively (Fig. 5). To the other phylum Firmicutes, only two isolates, EPS-20 and EPS-26, could be assigned. However, even though they formed a distinct subclade, their phylogenetic relationship with any particular species could not be resolved (Fig. 6).

\section{Secondary screening-disc diffusion and minimum inhibitory concentration}

For the second screening whereby the EPS from the eight isolates were further compared for their antibacterial activity, significant differences were observed between the growthinhibiting properties of the eight EPS $(p<0.05)$. As shown in Table 2, only two extracts, namely E15 and E37, inhibited the growth of five and four additional test strains respectively. The remaining polysaccharides were active against less than half of the test strains. The same results were reflected in the MIC assays during which the eight EPS were tested against the whole set of 14 pathogens. In this case, only E15 and E37 inhibited the growth of at least 10 test pathogenic strains (Table 3). The minimum recorded MIC value was $62.5 \mu \mathrm{g} / \mathrm{ml}$ for E37 against Salmonella typhimurium while the rest of the values varied between 125 and $500 \mu \mathrm{g} / \mathrm{ml}$. As far as the other extracts were concerned, they were inactive against most of the pathogens, except for E26 which was inhibitory to up to seven strains. MIC values, in these cases, ranged from 500 to $2000 \mu \mathrm{g} / \mathrm{ml}$.

Fig. 3 Neighbour-joining tree based on 16S rRNA sequences showing the relationship of isolate EPS-37 with other strains from the Alcaligenaceae family. Bootstrap values (expressed as percentages of 1000 replications) $\geq 50$ are shown at branch nodes. represent nodes obtained for all phylogenetic trees while 0 represent nodes obtained only on two of the tree topologies. Number in parentheses indicates GenBank nucleotide accession numbers. Oxalobacter vibrioformis $\mathrm{WoOx} 3$ was chosen as outgroup. Bar represents 0.007 substitution per nucleotide position

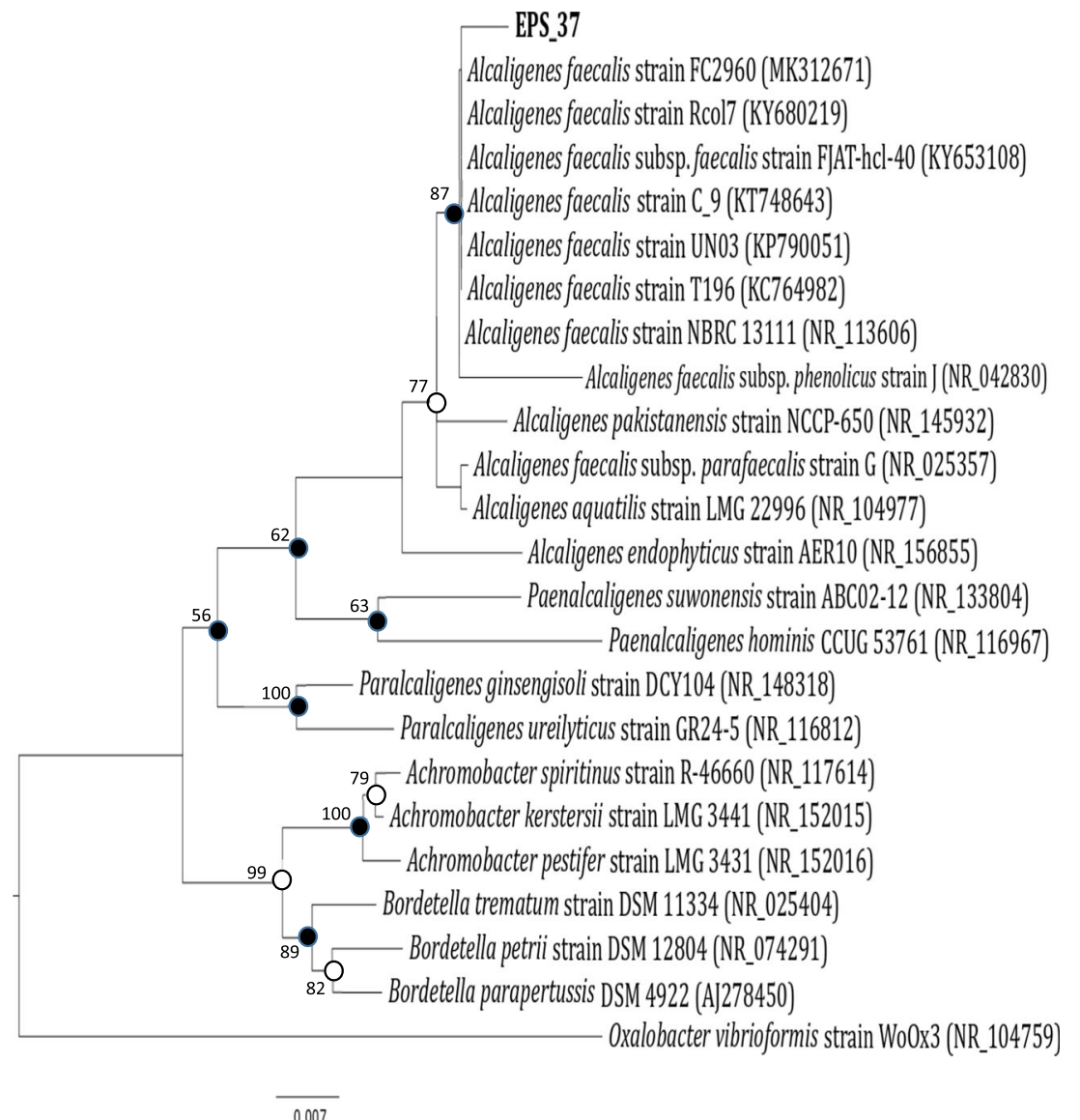

0.007 
Fig. 4 Neighbour-joining tree based on 16S rRNA sequences showing the relationship of isolate EPS-5 with other strains from the Moraxellaceae family. Bootstrap values (expressed as percentages of 1000 replications) $\geq 50$ are shown at branch nodes. - represent nodes obtained for all phylogenetic trees while $\mathbf{O}$ represent nodes obtained only on two of the tree topologies. Number in parentheses indicate GenBank nucleotide accession numbers. Pseudomonas aeruginosa DSM 50071 was chosen as outgroup. Bar represents 0.02 substitution per nucleotide position

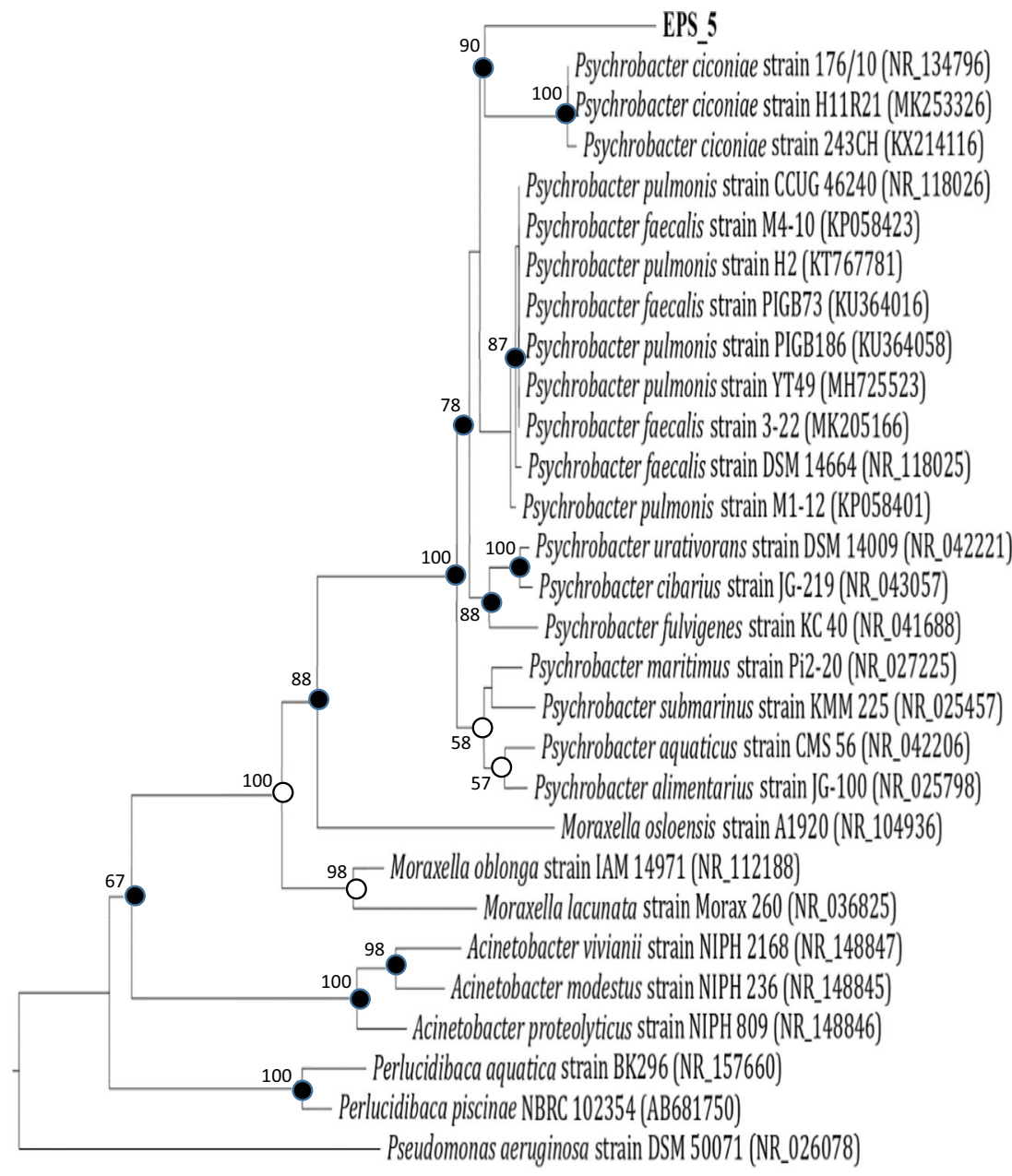

0.02

\section{Chemical characterisation of extracellular polysaccharides and monosaccharide composition}

The two selected EPS extracts, E15 and E37, were both made up of around $60 \%$ sugar. E15 also had 6\% protein content, $22 \%$ sulphate content, with fructose being the main sugar detected while E37 had a sulphate content of 19\%, a protein content of $7 \%$ and consisted of glucose. The presence of amides was also detected in both extracts while the absence of uronic acids could also be noted.

\section{ATR-Fourier-transform infrared spectroscopy}

Based on the results of the screenings, E37 and E15 were therefore selected for analysis by ATR-FTIR, with Figs. 7 and 8 showing the spectra obtained. In the case of E37, the broad band at $3272 \mathrm{~cm}^{-1}$ and the less intense ones at 2919 and $2855 \mathrm{~cm}^{-1}$ could be assigned to hydrogen bonded $\mathrm{O}-\mathrm{H}$ stretching vibrations and to $\mathrm{C}-\mathrm{H}$ stretching variations respectively, common to polysaccharides (Ordóñez and Rupérez
2011). The signal at $1651 \mathrm{~cm}^{-1}$ could be attributed to a $C=O$ stretch of an acetyl or carbonyl group, with the peak at $1551 \mathrm{~cm}^{-1}$ being attributed to $\mathrm{N}-\mathrm{H}$ bonding of a secondary amide, which could be linked to protein presence (Chalkiadakis et al. 2013). Among other features, the peaks between 1329 and $1432 \mathrm{~cm}^{-1}$ were likely to represent the symmetric stretching of the carboxylate functional group $\left(\mathrm{COO}^{-}\right)$or its $\mathrm{C}-\mathrm{O}$ stretching bands (Kielak et al. 2017; Sardari et al. 2017). There was also the absorption at $1216 \mathrm{~cm}^{-1}$, suggesting an asymmetric stretching of sulphate ester O-S-O (Ordóñez and Rupérez 2011; Yang et al. 2012; Sardari et al. 2017). Finally, for the region from 1200 to $800 \mathrm{~cm}^{-1}$, often considered a fingerprint region used to characterise polysaccharides (Sajna et al. 2013), the strong peak at $1019 \mathrm{~cm}^{-1}$ could be assigned to ring stretching vibrations, $\mathrm{C}-$ $\mathrm{OH}$ bending as well as the coupled $\mathrm{C}-\mathrm{O}$ and $\mathrm{C}-\mathrm{C}$ stretching vibrations, all of which are characteristics of polysaccharides (Choma et al. 2013; Kielak et al. 2017). The peak at $826 \mathrm{~cm}^{-1}$ within this fingerprint region also suggested that E37 could consist of only of $\alpha$-glycosidic linkages, especially with the 
Fig. 5 Neighbour-joining tree based on 16S rRNA sequences showing the relationship of isolates EPS-15, EPS-16, EPSfrom the Halomonadaceae family. Bootstrap values (expressed as percentages of 1000 replications) $\geq 50$ are shown at branch nodes.

6 represent nodes obtained for all phylogenetic trees while $\mathbf{O}$ represent nodes obtained only on two of the tree topologies. Number in parentheses indicate GenBank nucleotide accession numbers. Marinomonas mediterranea MMB-1 was chosen as outgroup. Bar represents 0.008 substitution per nucleotide position 18 and EPS-19 with other strains

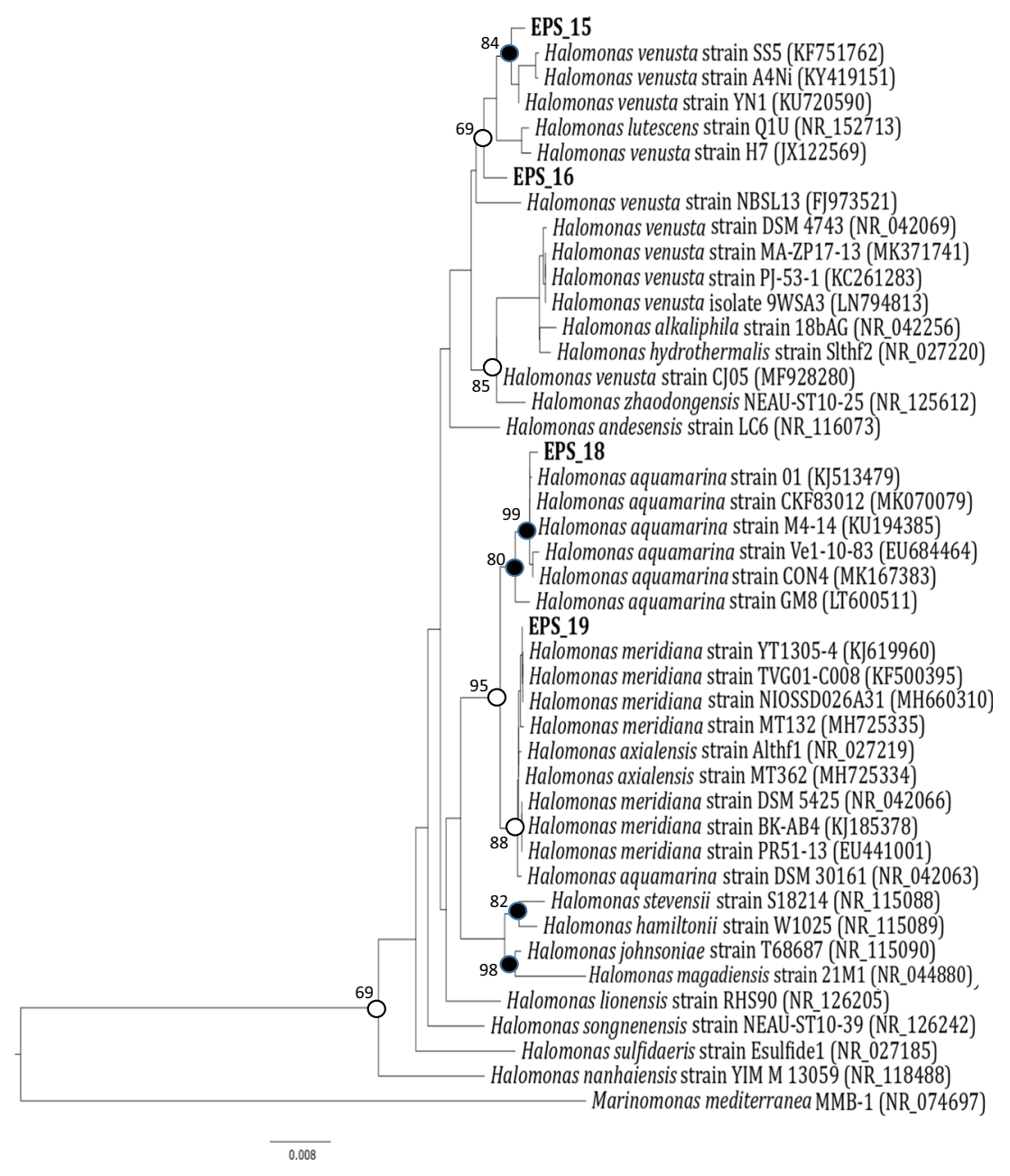

absence of any significant signal in the $890 \mathrm{~cm}^{-1}$ region, which would then have been indicative of $\beta$-glycosidic linkages (Kalyanasundaram et al. 2012; Du et al. 2017; Kielak et al. 2017). The spectrum for E15 (Fig. 8) had many of the peaks (between regions $500-1600 \mathrm{~cm}^{-1}$ and $3000-$ $4000 \mathrm{~cm}^{-1}$ ) corresponding to the same functional groups as those present in E37, except for the region 2000-2400 $\mathrm{cm}^{-1}$, which was more likely due to background noise within the spectrum.

\section{Discussion}

In this work, microorganisms isolated from seawater of Mauritius were screened for their ability to produce polysaccharides which exhibit antibacterial properties. Several authors have reported on the potential of exopolysaccharides as antimicrobial agents (Wilson et al. 2011; Karlapudi et al. 2016; Wu et al. 2016) and this property was demonstrated for EPS obtained from different types of microorganisms (Ghalem 2017; Jeong et al. 2017). Similarly, in this study, eight selected marine isolates were shown to produce EPS which could successfully inhibit the growth of human pathogenic bacteria. Since morphological- and biochemical-based methods were insufficient for their taxonomic classification, identification was largely based on their 16S rRNA sequences through phylogenetic analyses.

Phylogeny generated indicated that EPS-37 could be identified as Alcaligenes faecalis as it clusters together with other A. faecalis strains with strong support (Fig. 3). In fact, our isolate clustered with species obtained from different environments, suggesting that $A$. faecalis strains, including EPS-37 could be more of a ubiquitous strain rather than a strictly marine one. The other isolate, EPS-5, which could be assigned to the genus Psychrobacter, was more closely related to P. ciconiae. Psychrobacter species are known to be halotolerant (Romanenko et al. 2002) and it could be that our isolate shares similar halotolerance characteristics. However, further investigations are needed to confirm same as Kämpfer et al. (2015) isolated $P$. ciconiae as a new species from white stork nestling in a non-marine environment. Our phylogeny also depicts EPS-5 as a separate lineage from the P. ciconiae group (Fig. 4) and this isolate shares only $96.1 \%$ nucleotide sequence similarity with the type strain. A 
Fig. 6 Neighbour-joining tree based on 16S rRNA sequences showing the relationship of isolates EPS-20 and EPS-26 with other strains from the Bacillaceae family. Bootstrap values (expressed as percentages of 1000 replications) $\geq 50$ are shown at branch nodes. represent nodes obtained for all phylogenetic trees while $\mathbf{0}$ represent nodes obtained only on two of the tree topologies. Number in parentheses indicate GenBank nucleotide accession numbers. Staphylococcus saprophyticus ATCC 15305 was chosen as outgroup. Bar represents 0.02 substitution per nucleotide position

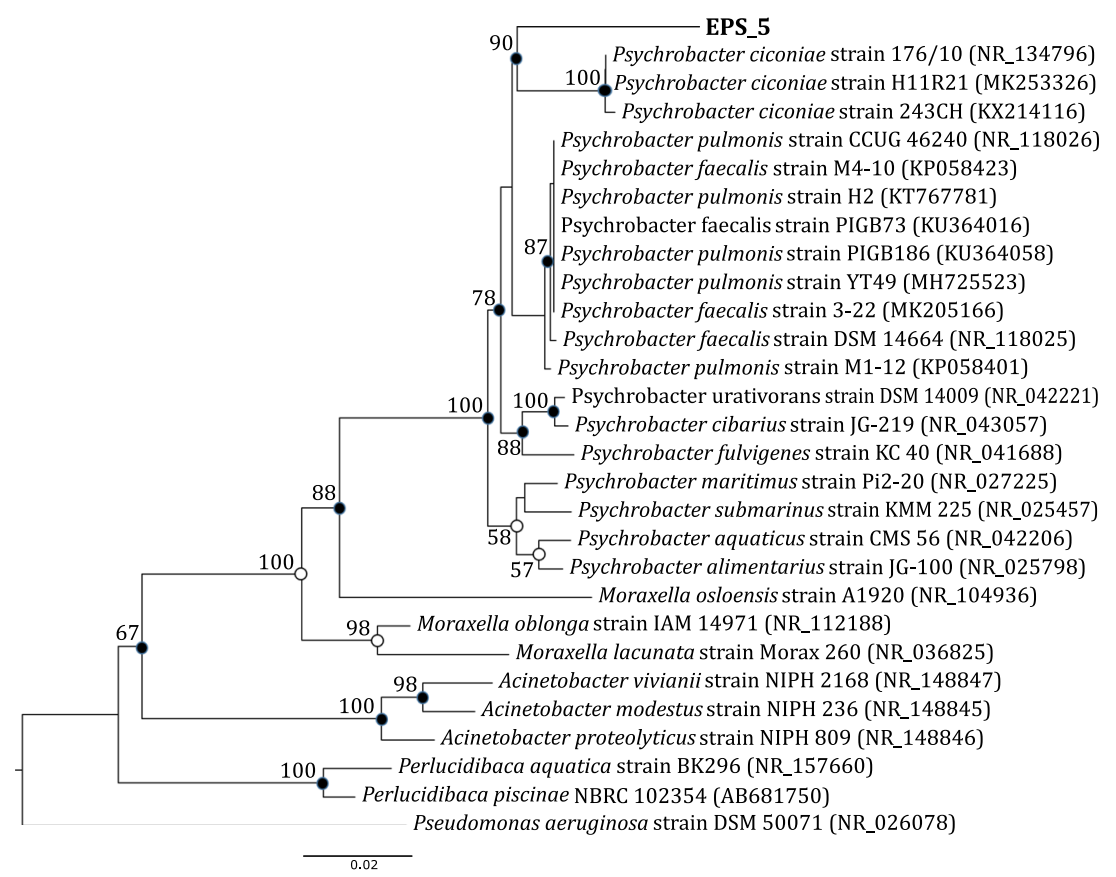

sequence similarity value less than $98.6 \%$ in $16 \mathrm{~S}$ rRNA with the closest type strain has been suggested to indicate a new species (Kim et al. 2014; Chun et al. 2018) and in fact, for this particular genus, values higher than this threshold have also been reported for novel Psychrobacter species (Zeng et al. 2016). Moreover, EPS-5 does show physical differences from the features of $P$. ciconiae described by Kämpfer et al. (2015), especially concerning its coccus shape and sugar utilisation. This indicates that EPS-5 could potentially represent a new species but further investigations are warranted.

Four of our selected isolates (EPS-15, EPS-16, EPS-18 and EPS-19) could be assigned to the genus Halomonas. Members of this genus are well known to be halophilic species (Wang et al. 2007) and therefore, can adapt well to saline conditions. In this case, phylogenetic analyses supported the identities of EPS-15 and EPS-16 as H. venusta as well as those of EPS-18 and EPS-19 as $H$. aquamarina and $H$. meridiana respectively (Fig. 5). On the other hand, the identification of isolates EPS20 and EPS-26 was limited to genus level. They clustered along with other Bacillus species (e.g. B. paramycoides, B. anthracis, B. cereus, B. thuringiensis) but this subclade (Fig. 6) received moderate support and phylogenetic relationships with any particular species within the clade could not be resolved (sequence variation was very minimal). In fact, there has been concerns on the reliability of $16 \mathrm{~S}$ rRNA sequences to delineate species with high level of nucleotide similarities (Janda and Abbott 2007; Woo et al. 2009) and other genes exhibiting more sequence variability are needed. This applies particularly for species such as Bacillus cereus and its close relatives whereby classification is difficult given that high similarity was obvious even when whole genomes were compared (Schmidt et al. 2011; Okinaka and Keim 2016). This led

Table 2 Zones of inhibition $(\mathrm{mm})$ produced by each of the eight EPS for secondary screening

\begin{tabular}{|c|c|c|c|c|c|c|c|}
\hline & $\begin{array}{l}\text { Methicillin-resistant } \\
\text { Staphylococcus aureus }\end{array}$ & $\begin{array}{l}\text { Enterococcus } \\
\text { faecalis }\end{array}$ & $\begin{array}{l}\text { Streptococcus } \\
\text { pneumoniae }\end{array}$ & $\begin{array}{l}\text { Streptococcus } \\
\text { agalactiae }\end{array}$ & $\begin{array}{l}\text { Pseudomonas } \\
\text { aeruginosa }\end{array}$ & $\begin{array}{l}\text { Acinetobacter } \\
\text { sp. }\end{array}$ & $\begin{array}{l}\text { Campylobacter } \\
\text { jejuni }\end{array}$ \\
\hline \multicolumn{8}{|c|}{ EPS extract } \\
\hline E5 & $7.8 \pm 0.1$ & 0.0 & 0.0 & 0.0 & $7.4 \pm 0.4$ & 0.0 & 0.0 \\
\hline E15 & $10.0 \pm 0.1$ & $11.3 \pm 0.2$ & $9.4 \pm 0.2$ & $7.4 \pm 0.3$ & 0.0 & 0.0 & $9.5 \pm 0.1$ \\
\hline E16 & 0.0 & 0.0 & 0.0 & 0.0 & 0.0 & 0.0 & 0.0 \\
\hline E18 & 0.0 & 0.0 & 0.0 & 0.0 & 0.0 & 0.0 & 0.0 \\
\hline E19 & 0.0 & 0.0 & $7.5 \pm 0.1$ & 0.0 & $7.4 \pm 0.2$ & 0.0 & 0.0 \\
\hline E20 & 0.0 & 0.0 & $8.8 \pm 0.1$ & 0.0 & $7.4 \pm 0.3$ & 0.0 & $8.3 \pm 0.1$ \\
\hline E26 & $7.5 \pm 0.2$ & 0.0 & 0.0 & 0.0 & 0.0 & $7.6 \pm 0.3$ & 0.0 \\
\hline E37 & $8.8 \pm 0.2$ & 0.0 & $7.8 \pm 0.1$ & 0.0 & $7.6 \pm 0.1$ & 0.0 & $7.5 \pm 0.2$ \\
\hline
\end{tabular}

Values for zone of inhibition shown as diameter (in millimetres) \pm standard deviation 
Table 3 Minimum inhibitory concentration of selected EPS against pathogenic strains

Minimum inhibitory concentration $(\mu \mathrm{g} / \mathrm{ml})$

\begin{tabular}{lllllllllllllll}
\hline 1 & 2 & 3 & 4 & 5 & 6 & 7 & 8 & 9 & 10 & 11 & 12 & 13 & 14
\end{tabular}

EPS extract

\begin{tabular}{|c|c|c|c|c|c|c|c|c|c|c|c|c|c|c|}
\hline E5 & ni & 1000 & 500 & ni & ni & ni & 2000 & ni & 2000 & ni & ni & ni & ni & ni \\
\hline E15 & 250 & 250 & 250 & ni & ni & 250 & 500 & 250 & 250 & 250 & ni & ni & 250 & 500 \\
\hline E16 & $\mathrm{ni}$ & 1000 & 500 & ni & ni & ni & 2000 & $\mathrm{ni}$ & 1000 & 500 & ni & ni & ni & 2000 \\
\hline E18 & ni & ni & ni & ni & ni & ni & ni & ni & ni & ni & ni & ni & ni & ni \\
\hline E19 & ni & ni & ni & ni & ni & ni & ni & ni & ni & 500 & 500 & ni & $\mathrm{ni}$ & ni \\
\hline E20 & ni & ni & ni & ni & ni & ni & ni & ni & ni & 500 & 500 & ni & ni & 250 \\
\hline E26 & ni & 500 & 500 & ni & 500 & 500 & 2000 & 2000 & 2000 & ni & ni & ni & ni & ni \\
\hline E37 & 250 & 500 & 250 & ni & 62.5 & 500 & 250 & 500 & 250 & 250 & 250 & ni & ni & 125 \\
\hline
\end{tabular}

1-Bacillus cereus, 2-Staphylococcus aureus, 3-Staphylococcus saprophyticus, 4-Escherichia coli, 5-Salmonella typhimurium, 6-Enterobacter cloacae, 7-Proteus mirabilis, 8-methicillin-resistant Staphylococcus aureus, 9-Enterococcus faecalis, 10-Streptococcus pneumoniae, 11Streptococcus agalactiae, 12-Pseudomonas aeruginosa, 13-Acinetobacter sp., 14 -Campylobacter jejuni; ni no inhibition

to the suggestion that they could be genetically classified as the same organism (Zahner et al. 2013). However, even though DNA-DNA hybridisation values less than the $70 \%$ threshold indicated that they were indeed distinct organisms (Guinebretière et al. 2013), the species of this subclade are often referred to as the Bacillus cereus group (Ceuppens et al. 2013; Zahner et al. 2013) but to avoid nomenclatural confusion, we label our isolate as an unidentified Bacillus species.

In this study, several isolated marine microorganisms were shown to produce EPS which could successfully inhibit the growth of human pathogenic bacteria, with Gram-negative bacteria being more susceptible than the Gram-positive ones, except for Staphylococcus aureus which was also very susceptible. These two types of bacteria differ in their cell walls, with Gram-negative bacteria having a thinner one as well as an outer layer compared to Gram-positive bacteria (Silhavy et al. 2010; Brown et al. 2015). Hence, the observed differences in susceptibility could very likely be due to the way in which the EPS interact with the different cell walls. In fact, the efficiency of other antimicrobial compounds has also been linked with differences in the cell walls between the two types of bacteria (Prochnow et al. 2016). This includes the polysaccharide chitosan, for which its positively charged structure and hydrophilic nature is considered essential for antimicrobial activity against Gram-negative bacteria (Kong et al. 2010) since the thin surfaces of these organisms are negatively charged, resulting in electrostatic interactions which may not only disrupt cell wall permeability but also cause its hydrolysis and subsequent leakage of cell contents (Goy et al. 2009). However, it should be noted that, as far as chitosan is concerned, there are conflicting reports on which group of bacteria is more susceptible (Kong et al. 2010). In addition to this, the growth of Gram-positive organisms such as Staphylococcus aureus was also inhibited while no effect on Escherichia coli, a Gram-negative one, was observed.
Fig. 7 FTIR spectra of E37, showing peaks in the range $4000-400 \mathrm{~cm}^{-1}$

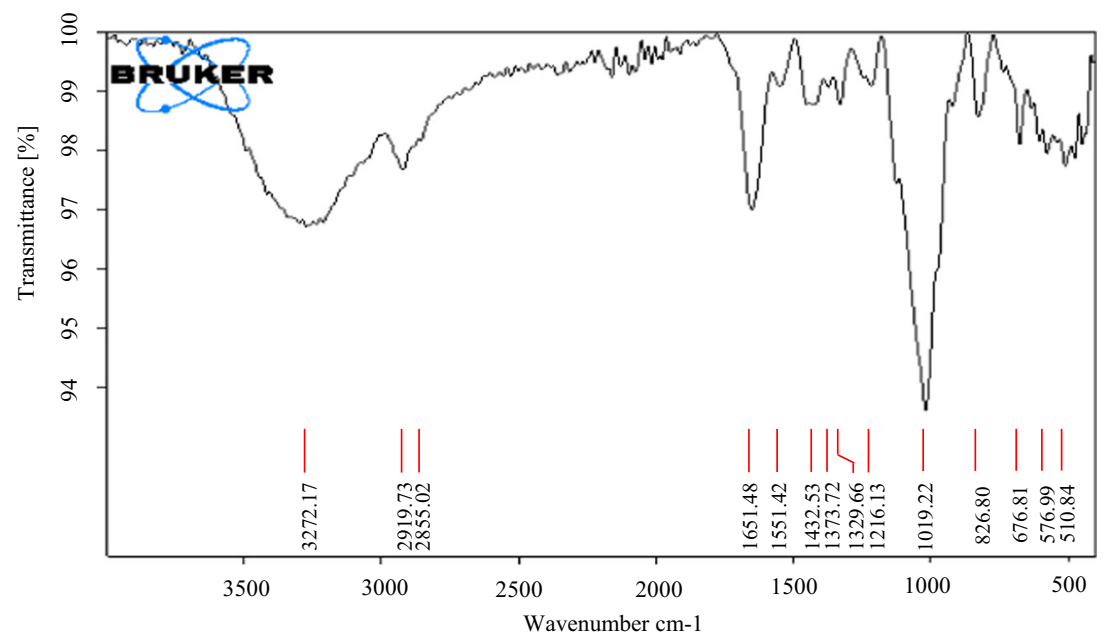


Fig. 8 FTIR spectra of E15, showing peaks in the range 4000 $400 \mathrm{~cm}^{-1}$

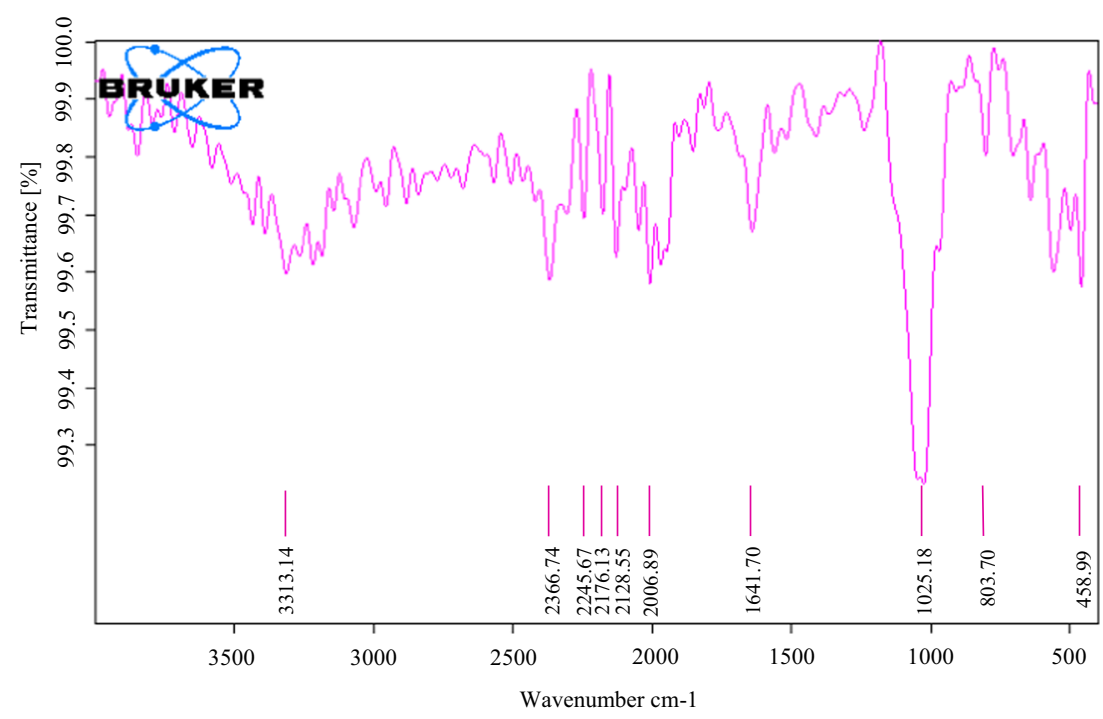

These suggest that the mechanism of action of the isolated exopolysaccharides could be more complex than simple interaction with the bacterial cell walls.

The secondary screening as well as the MIC assays allowed the EPS from the eight isolates to be further differentiated based on their antibacterial activity and eventually polysaccharide extracts E15 and E37, from isolates EPS-15 (Halomonas sp.) and EPS-37 (Alcaligenes faecalis) respectively, were found to be particularly effective against most pathogens. Interestingly, antibacterial EPS of organisms from these two genera is not widely documented and both sets of screenings indicated that polysaccharides from Halomonas and Alcaligenes species might be promising antimicrobial agents against various pathogenic strains. In fact, one of their most promising features was the inhibitory effect exerted on Staphylococcus aureus, including methicillin-resistant Staphylococcus aureus (MRSA). The latter is a major cause of nosocomial infections (Dakheel et al. 2016) and its incidence has been on the rise, becoming a growing public health concern, especially due to its resistance to a wide range of antibiotic treatment (Sardi et al. 2017; Neopane et al. 2018). Although antimicrobial activity of EPS has been studied against different pathogenic strains, their effectiveness against MRSA has not been widely investigated. These results may, therefore, help to further study the different ways in which antimicrobial polymers such as EPS can be further used, along with known drugs, to develop more effective treatments against pathogenic microorganisms, especially antibiotic-resistant ones.

The use of FTIR allowed the determination of functional groups present in E15 and E37 for identifying those which could be linked to the observed bioactivity. The spectra for both extracts did not show major differences, with the presence of groups such as carbonyl, amine or even hydroxyl being observed in both. These functional groups have the ability to chelate metal ions (Collin et al. 2015) and this property is more often exploited for bioremediation purposes
(Philippis et al. 2011; Gupta and Diwan 2017). However, the ability to sequestrate metal ions has also been suggested as a potential mechanism for antimicrobial activity, including for the polysaccharide chitosan (Sebat et al. 2001; Kong et al. 2010; Qiu et al. 2011). Indeed, metal ions are essential as nutrients for microbial growth and at the same time, are required for the stability of microbial cell walls by combining with molecules within the walls (Goy et al. 2009; Kong et al. 2010). Hence, through the chelation process, the availability of metal ions to microorganisms are reduced and this could have also contributed to the observed antibacterial properties.

The FTIR results as well as the compositional analysis of E37 and E15 also showed that they bear some similarity with the polysaccharides curdlan and levan respectively. This is likely given that these two polymers can be produced by Alcaligenes and Halomonas species, the same genera to which the isolates producing E37 and E15 belong. Interestingly, although the antibacterial properties of curdlan and levan is known (Byun et al. 2014; Chen and Liang 2017), their effectiveness against a wide range of microbial pathogens, as carried out in this study, has not been investigated. Hence, even though further structural characterisation is required to assess the extent to which E15 and E37 is similar to curdlan and levan, yet the observed antibacterial properties in this work suggests that both curdlan and levan might also exhibit biological activities against a wide array of pathogens. Furthermore, it was interesting to note the presence of sulphate groups in the two extracts since sulphate-containing polysaccharides of marine origin are quite important for industries (Ladrat et al. 2014). In fact, these have been attracting attention due to a number of their unique physico-chemical properties (Raveendran et al. 2013) as well as a number of their biological properties (Jesus Raposo et al. 2013; El Essawy et al. 2016; Heymann et al. 2016), thereby further highlighting the potential of the two isolated exopolysaccharides as bioactive compounds. 


\section{Conclusion}

The search for new compounds of biotechnological value has greatly fuelled the need to probe new environments. In this work, Mauritius seawater, a relatively underexplored one, has been shown to harbour different microbial species, especially those which can produce antibacterial exopolysaccharides. Among these exopolysaccharides, two sulphated ones seemed promising as inhibitors of the growth of human bacterial pathogens, including antibiotic-resistant ones. Although further work is required to assess their suitability as antibacterial agents, this work highlights the potential of using the isolated polymers in the development of new drugs or more effective treatments. Furthermore, this study shows that Mauritius seawater can be a source of biotechnologically useful microorganisms producing compounds of potential value.

Acknowledgements The authors wish to thank the Faculty of Agriculture, Faculty of Science, CBBR and University of Mauritius for supporting this study. The support of the technical staff of the Department of Agriculture \& Food Science as well as the Department of Chemistry is gratefully acknowledged.

Funding This work was supported by a grant from the University of Mauritius (grant number Q0117).

\section{Compliance with ethical standards}

Conflict of interest The authors declare that they have no conflict of interest.

Research involving human participants and/or animals This article does not contain any studies with human participants or animals performed by any of the authors.

Informed consent N/A

\section{References}

Al-Nahas MO, Darwish MM, Ali AE, Amin MA (2011) Characterization of an exopolysaccharide-producing marine bacterium, isolate Pseudoalteromonas sp. AM. Afr J Microbiol Res 5(22):38233831. https://doi.org/10.5897/AJMR11.757

Balouiri M, Sadiki M, Ibnsouda SK (2016) Methods for in vitro evaluating antimicrobial activity: a review. J Pharm Anal 6(2):71-79. https://doi.org/10.1016/j.jpha.2015.11.005

Balzaretti S, Taverniti V, Guglielmetti S, Fiore W, Minuzzo M, Ngo HN, Ngere JB, Sadiq S, Humphreys PN, Laws AP (2017) A novel rhamnose-rich heteroexopolysaccharide isolated from Lactobacillus paracasei DG activates THP-1 human monocytic cells. Appl Environ Microbiol 83(3):e02702-e02716. https://doi. org/10.1128/AEM.02702-16

Bragadeeswaran S, Jeevapriya R, Prabhu K, Rani SS, Priyadharsini S, Balasubramanian T (2011) Exopolysaccharide production by Bacillus cereus GU812900, a fouling marine bacterium. Afr J Microbiol Res 5(24):4124-4132. https://doi.org/10.5897/AJMR11.375

Brown L, Wolf JM, Rosales RP, Casadevall A (2015) Through the wall: extracellular vesicles in Gram-positive bacteria, mycobacteria and fungi. Nature Rev Microbiol 13(10):620-630. https://doi.org/10. 1038/nrmicro3480

Byun BY, Lee S, Mah J (2014) Antipathogenic activity and preservative effect of levan ( $\beta$-2,6-fructan), a multifunctional polysaccharide. Food Sci Technol 49:238-245. https://doi.org/10.1111/ijfs.12304

Ceuppens S, Boon N, Uyttendaele M (2013) Diversity of Bacillus cereus group strains is reflected in their broad range of pathogenicity and diverse ecological lifestyles. FEMS Microbiol Ecol 84(3):433-450. https://doi.org/10.1111/1574-6941.12110

Chalkiadakis E, Dufourcq R, Schmitt S, Brandily C, Kervarec N, Coatanea D, Amir H, Loubersac L, Chanteau S, Guezennec J, Rouzeyrol M, Colin C (2013) Partial characterization of an exopolysaccharide secreted by a marine bacterium, Vibrio neocaledonicus sp. nov., from New Caledonia. J Appl Microbiol 114(6):1702-1712. https://doi.org/10.1111/jam.12184

Chen M, Liang P (2017) Synthesis and antibacterial activity of quaternized curdlan. Polym Bulletin 74(10):4251-4266. https:// doi.org/10.1007/s00289-017-1951-0

Choma A, Wiater A, Komaniecka I, Paduch R, Pleszczynska M, Szczodrak J (2013) Chemical characterization of a water insoluble $(1 \rightarrow 3)$ - $\alpha$-D-glucan from an alkaline extract of Aspergillus wentii. Carbohydrates Pol 91(2):603-608. https://doi.org/10.1016/j. carbpol.2012.08.060

Chun J, Oren A, Ventosa A, Christensen H, Arahal DR, da Costa MS, Rooney AP, Yi H, Xu X, Meyer S, Trujillo ME (2018) Proposed minimal standards for the use of genome data for the taxonomy of prokaryotes. I J Syst Evol Microbiol 68:461-466. https://doi.org/10. 1099/ijsem.0.002516

Cojoc R, Merciu S, Oancea P, Pincu E, Dumitru L, Enache M (2009) Highly thermostable exopolysaccharide produced by the moderately halophilic bacterium isolated from a man-made young salt lake in Romania. Polish J Microbiol 58(4):289-294 ISSN: 1733-1331

Collin C, Gueguen Y, Bachere E, Kouzayha A, Saulnier D, Gayet N, Guezennec J (2015) Use of natural antimicrobial peptides and bacterial biopolymers for cultured pearl production. Mar Drugs 13: 3732-3744. https://doi.org/10.3390/md13063732

Dakheel KH, Rahim RA, Neela VK, Al-Obaidi JR, Hun TG, Yusoff K (2016) Methicillin-resistant Staphylococcus aureus biofilms and their influence on bacterial adhesion and cohesion. Biomed Res Int 2016:4708425. https://doi.org/10.1155/2016/4708425

Darriba D, Taboada GL, Doallo R, Posada D (2012) jModelTest 2: more models, new heuristics and parallel computing. Nat Methods 9(8): 772. https://doi.org/10.1038/nmeth.2109

Debbab A, Aly AH, Lin WH, Proksch P (2010) Bioactive compounds from marine bacteria and fungi. Microb Biotechnol 3(5):544-563. https://doi.org/10.1111/j.1751-7915.2010.00179.x

Dinić M, Pecikoza U, Djokić J, Stepanović-Petrović R, Milenković M, Stevanović M, Filipović N, Begović J, Golić N, Lukić J (2018) Exopolysaccharide produced by probiotic strain Lactobacillus paraplantarum BGCG11 reduces inflammatory hyperalgesia in rats. Front Pharmacol 9(1). https://doi.org/10.3389/fphar.2018.00001

Du B, Yang Y, Bian Z, Xu B (2017) Characterization and antiinflammatory potential of an exopolysaccharide from submerged mycelial culture of Schizophyllum commune. Front Pharmacol 8(252). https://doi.org/10.3389/fphar.2017.00252

Dubois M, Gilles KA, Hamilton JK, Rebers PA, Smith F (1956) Calorimetric method for determination of sugars and related substances. Anal Chem 28(3):350-356. https://doi.org/10.1021/ ac60111a017

El Essawy AK, Abu Shady HM, Abu El Kher AM, Helal MM (2016) Antimicrobial, anticoagulation, fibrinolytic and prebiotic activities of exopolysaccharide produced by marine Klebsiella Sp. Egypt. J Exp Biol (Bot) 12(2):267-274. ISSN: 2090 - 0503. https://doi.org/ 10.5455/egyjebb.20161115114843

El-Deeb NM, Yassin AM, Al-Madboly LA, El-Hawiet A (2018) A novel purified Lactobacillus acidophilus 20079 exopolysaccharide, LA- 
EPS-20079, molecularly regulates both apoptotic and NF-kB inflammatory pathways in human colon cancer. Microb Cell Factories 17:29. https://doi.org/10.1186/s12934-018-0877-z

El-Naggar ME, Abdelgawad AM, Salas C, Rojas OJ (2016) Curdlan in fibers as carriers of tetracycline hydrochloride: controlled release and antibacterial activity. Carbohydr Polym 154(10):194-203. https://doi.org/10.1016/j.carbpol.2016.08.042

Eloff JN (1998) A sensitive and quick microplate method to determine the minimal inhibitory concentration of plant extracts for bacteria. Planta Med 64(8):711-713. https://doi.org/10.1055/s-2006-957563

Felsenstein J (1981) Evolutionary trees from DNA sequences: a maximum likelihood approach. J Mol Evol 17(6):368-376. https://doi. org/10.1007/BF01734359

Fitch WM (1971) Toward defining the course of evolution: minimum change for a specific tree topology. Syst Biol 20(4):406-416. https://doi.org/10.1093/sysbio/20.4.406

Frank JA, Reich CI, Sharma S, Weisbaum JS, Wilson BA, Olsen GJ (2008) Critical evaluation of two primers commonly used for amplification of bacterial 16S rRNA genes. Appl Environ Microbiol 74(8):2461-2470

Ghalem BR (2017) Antioxidant and antimicrobial activities of exopolysaccharides from yoghurt starter. Adv Biochem 5(5):97101. https://doi.org/10.11648/j.ab.20170505.13

Goy RC, Britto D, Assis OBG (2009) A review of the antimicrobial activity of chitosan. Polímeros 19(3):241-247 ISSN 1678-5169

Gugliandolo C, Spanò A, Lentini V, Arena A, Maugeri TL (2014) Antiviral and immunomodulatory effects of a novel bacterial exopolysaccharide of shallow marine vent origin. J Appl Microbiol 116(4):1028-1034. https://doi.org/10.1111/jam.12422

Guindon S, Gascuel O (2003) A simple, fast and accurate method to estimate large phylogenies by maximum-likelihood. Syst Biol 52(5):696-704. https://doi.org/10.1080/10635150390235520

Guinebretière MH, Auger S, Galleron N, Contzen M, Sarrau B, De Buyser ML, Lamberet G, Fagerlund A, Granum PE, Lereclus D, De Vos P, Nguyen-The C, Sorokin A (2013) Bacillus cytotoxicus sp. nov. is a novel thermotolerant species of the Bacillus cereus group occasionally associated with food poisoning. I J Syst Evol Microbiol 63:31-40. https://doi.org/10.1099/ijs.0.030627-0

Gupta P, Diwan B (2017) Bacterial exopolysaccharide mediated heavy metal removal: a review on biosynthesis, mechanism and remediation strategies. Biotechnol Rep (Amst) 13:58-71. https://doi.org/10. 1016/j.btre.2016.12.006

Heymann D, Velasco C, Chesneau J, Ratiskol J, Sinquin C, Jouault S (2016) Anti-metastatic properties of a marine bacterial exopolysaccharide-based derivative designed to mimic glycosaminoglycans. Molecules 21(3):309. https://doi.org/10.3390/ molecules21030309

Holt JG, Krieg NR, Sneath PHA, Staley JT, Williams ST (1994) Bergey's manual ${ }^{\circledR}$ of determinative bacteriology, 9th edn. Williams \& Wilkins, Maryland

Im S, Wang W, Lee C, Lee YN (2010) Activation of macrophages by exopolysaccharide produced by MK1 bacterial strain isolated from Neungee mushroom, Sarcodon aspratus. Immune Netw 10(6):230 238. https://doi.org/10.4110/in.2010.10.6.230

Janda JM, Abbott SL (2007) 16S rRNA gene sequencing for bacterial identification in the diagnostic laboratory: pluses, perils, and pitfalls. J Clin Microbiol 45(9):2761-2764. https://doi.org/10.1128/JCM. 01228-07

Jeong D, Kim D, Kang I, Kim H, Song K, Kim H, Seo K (2017) Characterization and antibacterial activity of a novel exopolysaccharide produced by Lactobacillus kefiranofaciens DN1 isolated from kefir. Food Control 78:436-442. https://doi. org/10.1016/j.foodcont.2017.02.033

Jesus Raposo MF, Morais RMSC, Morais AMMB (2013) Bioactivity and applications of sulphated polysaccharides from marine microalgae. Mar Drugs 11(1):233-252. https://doi.org/10.3390/md11010233
Ji C, Ji Y, Meng D (2013) Sulfated modification and anti-tumor activity of laminarin. Exp Ther Med 6(5):1259-1264. https://doi.org/10.3892/ etm.2013.1277

Jones KM (2012) Increased production of the exopolysaccharide Succinoglycan enhances Sinorhizobium meliloti 1021 symbiosis with the host plant Medicago truncatula. J Bacteriol 194(16): 4322-4331. https://doi.org/10.1128/JB.00751-12

Kalyanasundaram GT, Doble M, Gummadi SN (2012) Production and downstream processing of $(1 \rightarrow 3)-\beta$-D-glucan from mutant strain of Agrobacterium sp. ATCC 31750. AMB Express 2:31. https://doi. org/10.1186/2191-0855-2-31

Kämpfer P, Jerzak L, Wilharm G, Golke J, Busse H, Glaeser HP (2015) Psychrobacter ciconiae sp. nov., isolated from white storks (Ciconia ciconia). I J Syst Evol Microbiol 65:772-777. https://doi.org/10. 1099/ijs.0.000013

Karlapudi AP, Kodali VP, Kota KP, Shaik SS, Kumar NSS, Dirisala VR (2016) Deciphering the effect of novel bacterial exopolysaccharidebased nanoparticle cream against Propionibacterium acnes. 3 Biotech 6(1):35. https://doi.org/10.1007/s13205-015-0359-5

Khalil ES, Manap MY, Mustafa S, Amid M, Alhelli AM, Aljoubori A (2018) Probiotic characteristics of exopolysaccharides-producing Lactobacillus isolated from some traditional Malaysian fermented foods. CyTA J Food 16(1):287-298. https://doi.org/10.1080/ 19476337.2017.1401007

Kielak AM, Castellane TCL, Campanharo JC, Colnago LA, Costa OYA, Corradi da Silva ML, Veen JA, Lemos EGM, Kuramae EE (2017) Characterisation of novel Acidobacteria exopolysaccharides with potential industrial and ecological applications. Sci Rep 7(41193). https://doi.org/10.1038/srep41193

Kim M, Oh H, Park S, Chun J (2014) Towards a taxonomic coherence between average nucleotide identity and 16S rRNA gene sequence similarity for species demarcation of prokaryotes. I J Syst Evol Microbiol 64:346-351. https://doi.org/10.1099/ijs.0.059774-0

Kimura M (1980) A simple method for estimating evolutionary rates of base substitutions through comparative studies of nucleotide sequences. J Mol Evol 16(2):111-120. https://doi.org/10.1007/ BF01731581

Kong M, Chen XG, Xing K, Park HJ (2010) Antimicrobial properties of chitosan and mode of action: a state of the art review. I J Food Microbiol 144(1):51-63. https://doi.org/10.1016/j.ijfoodmicro. 2010.09.012

Ladrat C, Sinquin C, Lebellenger L, Zykwinska A, Joualt S (2014) Exopolysaccharides produced by marine bacteria and their applications as glycosaminoglycan-like molecules. Front Chem 2:85. https://doi.org/10.3389/fchem.2014.00085

Laurienzo P (2010) Marine polysaccharides in pharmaceutical applications: an overview. Mar Drugs 8(9):2435-2465. https://doi.org/10. 3390/md8092435

Liu S, Chen X, He H, Zhang X, Xie B, Yu Y, Chen B, Zhou B, Zhang Y (2013) Structure and ecological roles of a novel exopolysaccharide from the Arctic Sea ice bacterium Pseudoalteromonas sp. strain SM20310. Appl Environ Microbiol 79(1):224-230. https://doi.org/ 10.1128/AEM.01801-12

Lowry OH, Rosbrough NJ, Farr AL, Randall RJ (1951) Protein measurement with the Folin phenol reagent. J Biol Chem 193(1):265-275

Manca MC, Lama L, Improta R, Esposito E, Gambacorta A, Nicolaus B (1996) Chemical composition of two exopolysaccharides from Bacillus thermoantarcticus. Appl Environ Microbiol 62(9):32653269

Morsy MK, Sharoba AM, Khalaf HH, El-Tanahy HH, Cutter CN (2015) Efficacy of antimicrobial pullulan-based coating to improve internal quality and shelf-life of chicken eggs during storage. J Food Sci 80(5):1066-1074. https://doi.org/10.1111/1750-3841.12855

Moscovici M (2015) Present and future medical applications of microbial exopolysaccharides. Front Microbiol 6(1012). https://doi.org/10. 3389/fmicb.2015.01012 
Neopane P, Nepal HP, Shrestha R, Uehara O, Abiko Y (2018) In vitro biofilm formation by Staphylococcus aureus isolated from wounds of hospital-admitted patients and their association with antimicrobial resistance. Int J Gen Med 11:25-32. https://doi.org/10.2147/IJGM. S153268

Nichols CAM, Guezennec J, Bowman JP (2005) Bacterial exopolysaccharides from extreme marine environments with special consideration of the southern ocean, sea ice, and deep-sea hydrothermal vents: a review. Mar Biotechnol 7(4):253-271. https://doi. org/10.1007/s10126-004-5118-2

Nwodo UU, Green E, Okoh AI (2012) Bacterial exopolysaccharides: functionality and prospects. Int J Mol Sci 13(11):14002-14015. https://doi.org/10.3390/ijms 131114002

Okinaka RT, Keim P (2016) The phylogeny of Bacillus cereus sensu lato. Microbiol Spectr 4(1). https://doi.org/10.1128/microbiolspec.TBS0012-2012

Ordóñez E, Rupérez P (2011) FTIR-ATR spectroscopy as a tool for polysaccharide identification in edible brown and red seaweeds. Food Hydrocoll 25(6):1514-1520. https://doi.org/10.1016/j.foodhyd. 2011.02.009

Panthavee W, Noda M, Danshiitsoodol N, Kumagai T, Sugiyama M (2017) Characterization of exopolysaccharides produced by thermophilic lactic acid bacteria isolated from tropical fruits of Thailand. Biol Pharm Bull 40(5):621-629. https://doi.org/10.1248/bpb.b1600856

Pawar ST, Bhosale AA, Gawade TB, Nale TR (2013) Isolation, screening and optimization of exopolysaccharide producing bacterium from saline soil. J Microbiol Biotechnol Res 3(3):24-31 ISSN 2231-3168

Philippis R, Colica G, Micheletti E (2011) Exopolysaccharide-producing cyanobacteria in heavy metal removal from water: molecular basis and practical applicability of the biosorption process. Appl Microbiol Biotechnol 92(4):697-708. https://doi.org/10.1007/ s00253-011-3601-z

Poli A, Anzelmo G, Fiorentino G, Nicolaus B, Tommonaro G, Di Donato $P$ (2011) Polysaccharides from wastes of vegetable industrial processing: new opportunities for their eco-friendly re-use. In: Elnashar M (ed) Biotechnology of Polymers. InTech, London, pp 33-56

Prochnow A, Clauson M, Hong J, Murphy AB (2016) Gram positive and gram negative bacteria differ in their sensitivity to cold plasma. Sci Rep 6(38610). doi:10.1038/srep38610

Qiu D, Huang Z, Zhou T, Shen C, Hider RC (2011) In vitro inhibition of bacterial growth by iron chelators. FEMS Microbiol Lett 314(2): 107-111. https://doi.org/10.1111/j.1574-6968.2010.02153.x

Raveendran S, Poulose AC, Yoshida Y, Maekawa T, Kumar DS (2013) Bacterial exopolysaccharide based nanoparticles for sustained drug delivery cancer chemotherapy and bioimaging. Carbohydrate Pol 91(1):22-32. https://doi.org/10.1016/j.carbpol.2012.07.079

Reichert M, Bergmann SM, Hwang J, Buchholz R, Lindenberger C (2017) Antiviral activity of exopolysaccharides from Arthrospira platensis against koi herpesvirus. J Fish Dis 40(10):1441-1450. https://doi.org/10.1111/jfd.12618

Romanenko LA, Schumann P, Rohde M, Lysenko AM, Mikhailov VV, Stackebrandt E (2002) Psychrobacter submarinus sp. nov. and Psychrobacter marincola sp. nov., psychrophilic halophiles from marine environments. I. J Syst Evol Microbiol 52:1291-1297. https://doi.org/10.1099/ijs.0.02087-0

Saitou N, Nei M (1987) The neighbor-joining method: a new method for reconstructing phylogenetic trees. Mol Biol Evol 4(4):406-425. https://doi.org/10.1093/oxfordjournals.molbev.a040454

Sajna KV, Sukumaran RK, Gottomukkala JD, Jayamurthy H, Dhar KS, Pandey A (2013) Studies on structural and physical characteristics of a novel exopolysaccharide from Pseudozyma sp. NII 08165. I J Biol Macromol 59:84-89. https://doi.org/10.1016/j.ijbiomac.2013.04.025

Sardari RRR, Kulcinskaja E, Ron EYC, Björnsdóttirc S, Friðjónsson OH, Hreggviðsson GO, Karlsson EN (2017) Evaluation of the production of exopolysaccharides by two strains of the thermophilic bacterium Rhodothermus marinus. Carbohydrate Pol 156:1-8. https://doi.org/10.1016/j.carbpol.2016.08.062

Sardi JCO, Polaquini CR, Freires IA, Galvão LCC, Lazarini JG, Torrezan GS, Regasini LO, Rosalen PL (2017) Antibacterial activity of diacetylcurcumin against Staphylococcus aureus results in decreased biofilm and cellular adhesion. J Med Microbiol 66:816824. https://doi.org/10.1099/jmm.0.00049

Schmidt TR, Scott EJ, Dyer DW (2011) Whole-genome phylogenies of the family Bacillaceae and expansion of the sigma factor gene family in the Bacillus cereus species-group. BMC Genomics 12(430). https://doi.org/10.1186/1471-2164-12-430

Sebat JL, Paszczynski AJ, Cortese MS, Crawford RL (2001) Antimicrobial properties of pyridine-2, 6-dithiocarboxylic acid, a metal chelator produced by Pseudomonas spp. Appl Environ Microbiol 67(9):3934-3942. https://doi.org/10.1128/AEM.67.9. 3934-3942.2001

Sezer AD, Kazak SH, Rayaman E, Cevikbas A, Öner ET, Akbuğa J (2017) Development and characterization of vancomycin-loaded levan-based microparticular system for drug delivery. Pharm Dev Technol 22(5):627-634. https://doi.org/10.3109/10837450.2015. 1116564

Silhavy TJ, Kahne D, Walker S (2010) The bacterial cell envelope. Cold Spring Harb Perspect Biol 2(5). https://doi.org/10.1101/cshperspect. a000414

Singha TK (2012) Microbial extracellular polymeric substances: production, isolation and applications. IOSR J Pharm 2(2):276-281. http:// www.iosrphr.org/papers/v2i2/ZC022276281.pdf. Accessed 16 December 2018. https://doi.org/10.9790/3013-0220276281

Smibert RM, Krieg NR (1994) Phenotypic characterization. In: Gerhardt P, Murray R, Wood W, Krieg N (eds) Methods for general and molecular bacteriology. ASM Press, Washington DC, pp 607-654

Soria-Mercado IE, Villareal-Gomez LJ, Rivas GG, Sanchez NEA (2012) Bioactive compounds from bacteria associated to marine algae. In: Sammour RH (ed) Biotechnology - molecular studies and novel applications for improved quality of human life. In-Tech, London, pp 25-44

Sun M, Zhao F, Shi M, Zhang X, Zhou B, Zhang Y, Chen X (2015) Characterization and biotechnological potential analysis of a new exopolysaccharide from the Arctic marine bacterium Polaribacter sp. SM1127. Sci Rep 5:18435. https://doi.org/10.1038/srep18435

Swofford DL (2002) PAUP*. Phylogenetic analysis using parsimony ("and other methods). Version 4, Sinauer Associates, Sunderland Massachusetts

Thompson JD, Higgins DG, Gibson TJ (1994) CLUSTAL W: improving the sensitivity of progressive multiple sequence alignment through sequence weighting, position-specific gap penalties and weight matrix choice. Nucleic Acids Res 22(22):4673-4680. https://doi.org/ 10.1093/nar/22.22.4673

Trinetta V, Cutter CN (2016) Pullulan: a suitable biopolymer for antimicrobial food packaging applications. In: Barros-Velázquez J (ed) Antimicrobial food packaging. Academic Press, Waltham MA, pp 385-397

Vu B, Chen M, Crawford RJ, Ivanova EP (2009) Bacterial extracellular polysaccharides involved in biofilm formation. Molecules 14(7): 2535-2554. https://doi.org/10.3390/molecules14072535

Vuyst L, Vanderveken F, Van de Ven S, Degeest V (1998) Production by and isolation of exopolysaccharides from Streptococcus thermophilus grown in a milk medium and evidence for their growth-associated biosynthesis. J Appl Microbiol 84:1059-1068. https://doi.org/10.1046/j.1365-2672.1998.00445.x

Wang Y, Cai H, Chi C, Lu A, Lin X, Jiang Z, Wu X (2007) Halomonas shengliensis sp. nov., a moderately halophilic, denitrifying, crudeoil-utilizing bacterium. I J Syst Evol Microbiol 57:1222-1226. https://doi.org/10.1099/ijs.0.64973-0

Wen L, Xu Y, Wei Q, Chen W, Chen G (2018) Modeling and optimum extraction of multiple bioactive exopolysaccharide from an 
endophytic fungus of Crocus sativus L. Pharmacogn Mag 14(53): 36-43. https://doi.org/10.4103/pm.pm_96_17

Wilson K (2003) Preparation of genomic DNA from bacteria. In: Ausubel FM, Brent R, Kingston RE, Moore DD, Seidman JG, Smith JA, Struhl K (eds) Current protocols in molecular biology. John Wiley \& Sons Inc., Somerset NJ, pp 2.4.1-2.4.5

Wilson GS, Raftos DA, Nair SV (2011) Antimicrobial activity of surface attached marine bacteria in biofilms. Microbiol Res 166(6):437448. https://doi.org/10.1016/j.micres.2010.08.003

Woo PCY, Teng JLL, Wu JKL, Leung FPS, Tse H, Fung AMY, Lau SKP, Yuen K (2009) Guidelines for interpretation of 16S rRNA gene sequence-based results for identification of medically important aerobic gram-positive bacteria. J Med Microbiol 58(Pt 8):1030-1036. https://doi.org/10.1099/jmm.0.008615-0

Wu S, Liu G, Jin W, Xiu P, Sun C (2016) Antibiofilm and anti-infection of a marine bacterial exopolysaccharide against Pseudomonas aeruginosa. Front Microbiol 7:102. https://doi.org/10.3389/fmicb. 2016.00102

Yadav V, Prappulla SG, Jha A, Poonia A (2011) A novel exopolysaccharide from probiotic Lactobacillus fermentum CFR 2195: production, purification and characterization. Biotechnol Bioinf Bioeng 1(4):415-421 ISSN 2249-9075

Yang W, Pei F, Shi Y, Zhao L, Fang Y, Hu Q (2012) Purification, characterization and anti-proliferation activity of polysaccharides from Flammulina velutipes. Carbohydrates Pol 88(2):474-480. https:// doi.org/10.1016/j.carbpol.2011.12.018

Yoon SH, Ha SM, Kwon S, Lim J, Kim Y, Seo H, Chun J (2017) Introducing EzBioCloud: a taxonomically united database of $16 \mathrm{~S}$
rRNA and whole genome assemblies. Int J Syst Evol Microbiol 67: 1613-1617

Zahner V, Silva ACTC, Moraes GP, McIntosh D, Filippis I (2013) Extended genetic analysis of Brazilian isolates of Bacillus cereus and Bacillus thuringiensis. Mem Inst Oswaldo Cruz 108(1):65-72. https://doi.org/10.1590/S0074-02762013000100011

Zeng Y, Yu Y, Liu Y, Li H (2016) Psychrobacter glaciei sp. nov., isolated from the ice core of an Arctic glacier. I J Syst Evol Microbiol 66: 1792-1798. https://doi.org/10.1099/ijsem.0.000939

Zhang Z, Zhou Z, Li Y, Zhou L, Ding Q, Xu L (2016) Isolated exopolysaccharides from Lactobacillus rhamnosus $\mathrm{GG}$ alleviated adipogenesis mediated by TLR2 in mice. Sci Rep 6:36083. https:// doi.org/10.1038/srep36083

Zheng LH, Wang YJ, Sheng J, Wang F, Zheng Y, Lin XK, Sun M (2011) Antitumor peptides from marine organisms. Mar Drugs 9:1840 1859. https://doi.org/10.3390/md9101840

Zhou X, Hong T, Yu Q, Nie S, Gong D, Xiong T, Xie M (2017) Exopolysaccharides from Lactobacillus plantarum NCU116 induce c-Jun dependent Fas/Fasl-mediated apoptosis via TLR2 in mouse intestinal epithelial cancer cells. Sci Rep 7:14247. https://doi.org/10. 1038/s41598-017-14178-2

Publisher's note Springer Nature remains neutral with regard to jurisdictional claims in published maps and institutional affiliations. 